Symbolon Volume XXII. no. 2 (41)

\title{
Menekülés a komplexitástól
}

DOI : $10.46522 / \mathrm{S} .2021 .02 .01$

\section{CSEPELI György PhD}

Eötvös Lóránd University of Sciences, Faculty of Social Sciences, Institute for Social Relations, Institute of Advanced Studies at Köszeg (IASK) csepeli.gyorgy@iask.hu

\begin{abstract}
Escape From Complexity
As a result of the recently occurred pandemic it has become apparent even for the common people that reality no longer can be seen through the lenses of simplification. Humankind has entered a new age characterized by complexity and lack of transparency. The border between nature and society has disappeared revealing that both of them are ruled by laws of complex systems. The relationships in complex systems are non-linear, categories are bond to language and understanding is a function of fuzzy logic. There is one chaordic world where changes cannot be predicted. Sudden small changes can lead to major transformations. The human mind has not been equipped by evolution to the challenges of complexity. Human beings living complexity are driven to escape from insecurity to security. Instead of reducing tension infodemics in social media induce anxiety and a sense of insecurity resulting inadequate response of the users. As a consequence of cognitive inadaptation users of social media tend to develop symptoms of depression, anxiety, paranoia, irrational credulity and resistance to accept evidencebased communications.
\end{abstract}

Key words: complexity; freedom; modernization; credulity; infodemics.

A természeti világ, ahogyan magunk körül látjuk, világosan kijelöli a lehetetlen és a szükségszerü közötti teret, melynek történéseit törvények uralják. Aki ismeri a newtoni mechanikát, az tudja, hogy törvényei alól nincs kivétel, minden előre látható, bizonyos, és kontroll alatt tartható. Ezt a meggyőződést robbantotta fel, törte szét a kvantummechanika, mely szerint a látható világba rejtve ott van egy másik világ, melyet a véletlen, a kiszámíthatatlanság, a bizonytalanság, a valószínüség ural. A látható és a láthatatlan világ között ott van az ember, akinek agyában a kettő egymásra talál. A létező az emberre tekintve önmagára ismer.

A komplexitás a mechanika, kvantummechanika és az agy összjátéka nyomán feltárulkozó szerkezet, ahol nincs sem rend, sem káosz, hanem mindkettő együtt van. 
Ebben a szerkezetben nincs nyugalom, minden változik, de semmi sem előre látható. Kis változások beláthatatlan következményekkel járnak, de nincs magyarázat arra, hogy éppen mi mit okoz vagy nem okoz (Urry 2003).

A komplexitás alapelve a meghatározatlanság, amit az ember a maga létében szabadságként él meg. A szabadság az akarat, a választás, a teremtés és a rombolás ereje, mely az embert földre lépésének pillanatától a történelem végéig várhatóan végig kíséri.

A közösségi társadalmakban uralkodó lényegi akarat megkímélte a szabadság kihívásaitól az egyéneket, akiknek nem kellett szembesülniük a létükből következő hátborzongató idegenséggel, transzcendentális hajléktalansággal (Heidegger 2004; Lukács 2009). A közösségi társadalom lassú, de feltartóztathatatlan átalakulása következtében a választó akarat kiszabadult a lényegi akarat szorításából (Tönnies 2004). Elkezdődött a közösségi társadalmak modernizációja, melynek mozgatói a szabad, racionális gondolkodású, az egyházi autoritástól elszakadó, egyébként nem feltétlenül vallástalan egyének (Weber 1982).

Kiderült azonban, hogy nem mindenki képes a modern társadalom adta lehetőségekkel élni. Nem tud mindenki sikeresen vállalkozni, sokan félnek az igazságtól, iszonyodnak az Isten halála nyomán támadt nappali sötétségtől, nem tudnak mit kezdeni a szexualitás és az agresszivitás bennük tomboló erőivel. Számukra, mint a huszadik század elején a Frankfurti Iskola szociológusai kimutatták, nem marad más, mint a tekintélyek oltalma alá való húzódás, a szorongást csillapító merev gondolkodás, a tekintélyelvűség, vagy ahogyan a frankfurtiak egyike, Erich Fromm mondta találóan, menekülés a szabadság elöl.

A huszadik század társadalmai nem tudtak sikeres megoldásokat adni polgáraik számára a szabadsággal való megküzdésre. Bár az egyéni élet szintjén jelentösek a különbségek a huszadik században megjelent fogyasztói kapitalizmus, a bolsevizmus és a nemzeti szocializmus között, abban nem különböznek, hogy egyikük sem tủrte a személyiség autonómiáját, mely helyett a kívülröl irányított, „Akárkivé” silányított tömegember számára teremtettek teret. A huszadik század végén megjelent, és a huszonegyedik században kibontakozó, az embereket és a dolgokat az egész földi világon behálózó infokommunikációs ökoszisztéma azzal a veszéllyel fenyeget, hogy megvalósul a totális ellenőrzés orwelli rémálma (Zuboff 2019).

A Bibliában olvasható Belsazar babilóniai király története, aki palotájának egyik termében vendégei társaságában dőzsölve egyszer csak egy írást látott a terem falán, melynek jelentését utóbb a palotában élő Dániel próféta fejtette meg. A falon megjelent írás négy szót tartalmazott: Mene, Mene, Tekel, Ufarszin. Dániel megmondta a királynak, hogy a Mene azt jelenti, hogy számba vette Isten a te országlásodat, és véget vet annak. A Tekel szó jelentése: „megmérettél a mérlegen és híjával találtattál" (Dániel 5.28). 
A 2019-20-ban a világon végigsöprő s jelen sorok írása idején még véget nem ért koronavírus-járvánnyal megjelent az emberség hatalmasait fenyegető írás a falon, amely arra figyelmeztet, hogy civilizációnk válságba jutott. A járvány csak egyike a figyelmeztetéseknek, melyek sorában ott van a földi hőmérsékletet évröl évre növelö klímaválság, az emberi életre alkalmatlanná vált területekröl a szerencsésebb fekvésü régiók felé irányuló népvándorlás, a javak igazságtalan elosztása miatt keletkező fundamentalista ideológiákkal megtámogatott lázongás. A válság alapja minden bizonnyal a fenntarthatatlan növekedés, mely a környezetet kizsigerelve, a tartalékokat felélve olyan versenybe hajszolja az egyes országokat, melynek nem lesznek győztesei, csak vesztesei. A kapzsiság, a mohóság és az önzés végül a bünöst és az ártatlant egyaránt szakadékba viszi.

A komplexitás támadása elől a magukra hagyott emberek a hit menedékébe húzódnak, ahol egyszerü, hihető magyarázatokra találnak, amelyeket a közösségi média felhasználóiként egyszerre teremtenek és fogyasztanak. A mindenki számára hozzáférhető közösségi média platformjain nyüzsgő tömegek, mint azt Ortega y Gasset a múlt század 30-as éveiben oly világosan látta, fellázadtak a tekintélyek ellen (Ortega 1938). Az internetre lépő tömegek az új médium adta lehetőségeket kihasználva létrehozták a maguk kultúráját, politikáját, gazdaságát. Nem meglepő, hogy a komplexitás közérthető magyarázatára nem vállalkozó, homályosan fogalmazó, a mindennapi értelem számára felfoghatatlan tudomány nem talált utat a válságot megtapasztaló, de nem értő tömegekhez, melyek tagjai a rájuk zúduló dilemmákkal küszködve az antropológiai szempontból leginkább kézenfekvő megoldáshoz, a hithez folyamodtak. Makkai János, a méltatlanul elfelejtett magyar politikai gondolkodó 1943ban megjelent könyvét azzal a gondolattal kezdi, hogy ,az ember legfőbb, sőt minden élőlénytől elválasztó tulajdonsága, hogy hisz” (Makkai 1943, 12).

A bizonyítékot mellőző, a puszta hitből táplálkozó állítások lehetnek tagadóak vagy állítóak. Utóbbi esetben hiszékenységről, az előbbi esetben hitetlenségről beszélünk. Mindkét esetben az állítások igazolása nélkülözi a racionális ismeretszerzésben szokásos protokollt, melynek alapján az ismeretlenből az ismertbe a bizonyításon és/vagy a cáfolaton keresztül vezet az út.

A modernizáció egyáltalán nem tette általánossá a racionális megismerést, mely a komplex világ titkait a hétköznapi ember számára inkább elrejti, mintsem feltárja. Mind a mai napig sokan vannak, akik a Földet nap mint nap látván nem hiszik, hogy a Föld a Nap körül kering, s se szeri, se száma azoknak a balhiteknek, melyeknek alapja az illuzórikus korreláció, a csodavárás, a közösségi hisztéria.

A hétköznapi gondolkodás müködését magyarázó szakirodalom szerint ezeknek a balhiteknek az egyik gyakori alapja az elérhetőségi heurisztika, amit azt jelenti, hogy az ember a számára adott jelenségek magyarázatát nem abban az adatbázisban keresi, ahol a magyarázatot megtalálhatná. A magyarázat forrása a saját tapasztalat, mely óhatatlanul leszükített, korlátozott adatbázist jelent, amelynek alapján nem lehetséges az igazság felfejtése (Kahneman 2013). Súlyosbítja a helyzetet, hogy az igazságnak hitt 
önkényes tévtanok a társadalmi nyilvánosság terébe bekerülve hihetöségük, egyszerüségük, érzelmi töltésük folytán fölénybe kerülnek a tudományosan igazolható kijelentésekkel szemben. Ezt a tendenciát a közösségi média maximálisan felerösíti.

A hihető, ámde nem igaz állítások gyors terjedésének oka az is, hogy a tekintélyesnek számító forrásokból táplálkozó, a zárt gondolkodás rendjébe illeszkedő állítások alkalmasak a komplexitás okozta szorongás redukciójára, ami jelentősen megnöveli ellenállóképességüket a megváltoztatásukra irányuló szándékokkal szemben (Rokeach és Restle 1980).

A bizonyítható állításokkal szemben mutatkozó hitetlenség és a nem bizonyítható, puszta képzeleten vagy kitaláláson alapuló állításokkal szemben mutatkozó hiszékenység döntő oka, hogy az embert foglalkoztató lényegi, egzisztenciális kérdésekre nincsenek és nem is lesznek soha empirikusan igazolható, tudományos válaszok. Senki nem tud választ adni arra a kérdésre, hogy ki miért él a Földön, van-e vagy nincs Isten, mi az egyén életének célja, miért éppen ő, s nem más született a Földre. Az igazságon túli világ üzenete megerősíti az egyént léte igazában, identitást biztosít számára, mely segíti abban, hogy hajlékot találjon a transzcendentális hajléktalanságában, rendet leljen a rátörő kaotikus, komplex valóságban.

$\mathrm{Az}$ empirikusan bizonyítható igazság és az empirikusan bizonyíthatatlan látszatigazság között soha véget nem érő harc új színterei a vírusjárvány által sújtott társadalmak, melyek egyes tagjai a rohamosan terjedő, súlyos betegségekkel, esetenként halállal fenyegető vírustól megriadva a legkülönbözőbb balhitekbe menekültek. Új témára találva új életre keltek az összeesküvéselméletek (Kreko 2018). Mások viszont hitelt adtak a vírusra vonatkozó tudományos közléseknek, és a tudósok által javasolt védő intézkedésekkel igyekeztek a maguk és társaik életét megkímélni a vírus kártevéseitől. A vírussal kapcsolatos tévtanok és tudományos ismeretek követői közötti konfliktust súlyosbította, hogy a korlátozó intézkedések nemkívánatos következményeivel szembesülve a politikai döntéshozók számos országban maguk is ingadoztak a racionális és irracionális álláspontok között.

A rekordidő alatt megszületett vakcina lehetőséget adott a vírusjárvány megfékezésére, ám ekkor lábra kapott a vakcinaellenesség infodémiája, mely az elöítéletes, zárt gondolkodású, egymás hamis igazában bízó embereket tömegesen az oltás ellen hangolta. A legképtelenebb babonás mémek kaptak lábra, melyeket a közösségi média felhasználói járványszerüen terjesztettek és terjesztenek. Az oltásellenes influenszerek közül sokan belehaltak kampányukba, de ez nem tántorította el híveiket, akik nem adták fel oltásellenes álláspontjukat, éppen úgy, mint ahogyan a második világháború utolsó hónapjaiban a német csodafegyverek hívei állhatatosan várták Hitler győzelmét a Szövetséges és Társult Hatalmak ellen.

Mit tehet az ember, aki nem akar menekülni a komplexitás elől, s a kognitív kényelem helyett az igazsággal való kínzó szembenézést vállalja? A babonás, leegyszerüsítő, hihető, ám hamis állításokkal szemben a védekezés legjobb módszere a kritikai gondolkodás. Az első feladat a forráskritika. Bármilyen állításról legyen szó, 
gondosan meg kell vizsgálni az állítás forrását, s csak a hiteles forrásból szármató állítást szabad elfogadni. A tudományos kommunikációra szakosodott szervezeteknek igen nagy a felelőssége abban, hogy a hiteles tudományos hírek ne maradjanak alul az áltudományos híresztelésekkel folytatott versenyben.

A szuverén, szabad, kritikus gondolkodású egyén azonban nem születik készen, mint a Zeusz fejéböl készen kipattant Pallasz Athéné. A kritikai gondolkodásra való felkészítés az iskolában kezdődik, melynek az életkori sajátosságoknak megfelelően korosztályról-korosztályra meg kell tanítania az életbe lépő gyermekeket a kíváncsiságra, a csodálkozásra, a felfedezésre, meg kell őket ismertetni a természet- és társadalomtudomány nagy alkotóinak életével és munkásságával.

Csak az lehet szuverén felnőtt, akit szabadnak neveltek. A szuverén gondolkodó a rendkívüli, a szokatlan, a ritka, a váratlan végtelenbe vesző útjain elindulva vág a komplexitás titkainak felfedezésére, mely sosem lehet teljes. A halálba készülö Szókratész tanítványait arra kérte, hogy ne a tudás, hanem a nemtudás legyen számukra a kiindulópont. A tudás sziget a nem tudás tengerében. „Amit nem tudok, arról nem is hiszem, hogy tudom" - mondta Szókratész (Platón, 2005, 64). A komplexitás a szuverén, szabad gondolkodók hálózatában talál otthonra.

Kant hagyta ránk örökségül Horatius mondását: „Sapere aude!” Az emberi s az ember által alkotott mesterséges, gépi ész az empirikusan megismerhető valóság egyre nagyobb tartományait ragadja el a komplex, változékony, bizonytalan és kétértelmü komplexitás birodalmából. Van azonban egy másik, Nietzsche által szívesen hangoztatott mondás („Vivere aude!”), mely nem arra bíztat, hogy merjünk tudni, hanem arra, hogy merjünk élni.

A megmaradásunk azon múlik, hogy a bennünk és a rajtunk kívül lévő komplexitás egységében rádöbbenjünk a létezés egységére, és megtaláljuk a Földön élő hétmilliárdnyi ember számára méltó, igazságos és fenntartható élet politikai, gazdasági, kulturális és nem utolsósorban lélektani kereteit.

\section{KÖNYVÉSZET}

FROMM, E., 1993, Menekülés a szabadság elöl, ford. Bíró Dávid, Budapest, Akadémiai.

HEIDEGGER, M., 2004, Lét és idő, ford. Angyalosi Gergely, Bacsó Béla, Kardos András, Orosz István és Vajda Mihály, Budapest, Osiris.

KAHNEMAN, D., 2013, Gyors és lassú gondolkodás, ford.: Bányász Réka és Garai Attila, Budapest, HVG Könyvek.

KREKO P., 2018, Tömegparanoia. Az összeesküvéselméletek és az álhírek szociálpszichológiája, Budapest, Athenaeum.

LUKÁCS Gy., 2009, A regény elmélete, ford. Tandori Dezső, Budapest, Gond-Cura Alapítvány.

MAKKAI J., 1943, Politika - Isten rabságában, Budapest, szerzői kiadás. 
ORTEGA y GASSET, J., 1938, A tömegek lázadása, Budapest, Királyi Magyar Egyetemi Nyomda.

PLATÓN, 2005, Euthüphrón. Szókratész védőbeszéde. Kritón, ford. Gelencze-Miháltz Alirán és Mogyoródi Emese, Budapest, Atlantisz.

ROKEACH, M. és RESTLE, F., 1980, A nyílt és zárt gondolkodási rendszerek közötti alapvető különbségtevés. In Csepeli Gy. (szerk.), Elöitéletek és csoportközi viszonyok, Budapest, Közgazdasági és Jogi Kiadó, 295-315.

TÖNNIES, F., 2004, Közösség és társadalom, ford. Tatár György és Berényi Gábor, Budapest, Gondolat.

URRY, J., 2003, Global complexity, Cambridge: Polity.

WEBER, M., 1982, A protestáns etika és a kapitalizmus szelleme, ford. Gelléri Péter és Somlai Péter, Budapest, Gondolat.

ZUBOFF, S., 2019, The age of surveillance capitalism. The fight for a human future ad the new frontier of power, London, Profile Books. 